lead to long and unwieldy titles. For example, the East Greenland Caledonides will continue to be called just this, even though this tectonic unit stretches from East Greenland through North-East Greenland into North Greenland.

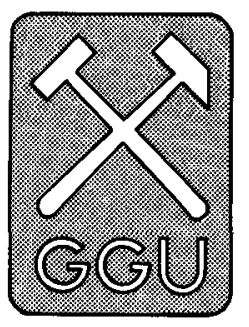

\title{
Geological mapping of Greenland
}

Geological maps provide an important means of documenting and advancing geological knowledge. As well as presenting detailed information in a practical way, geological maps are essential in assessing a region's geological history; they are prerequisite for meaningful evaluation of mineral resources.

Production of geological maps is one of the fundamental activities of geological surveys. In Greenland, both the initiation of geological mapping and the establishment of a geological survey have been late developments compared with many other countries. Consequently, national map coverage at a standard scale (in the case of Greenland, 1:500 000) is not yet complete. The sheer size of Greenland ( $2186000 \mathrm{~km}^{2}$ ), its arctic setting, severe climate and rugged topography are important factors that have governed overall mapping policy and field techniques.

\section{Historical background}

Historically, Greenland has attracted much international expeditionary activity. This exploration, together with work undertaken under early national government sponsorship that goes back to the beginning of the 19th century, has provided the fundamental knowledge on which geological mapping programmes could be based. In the later part of the 19th century efforts to foster a Greenland Survey met with short-lasting success. Although new initiatives were taken in the thirties, the war years intervened before the forerunner of the present Geological Survey of Greenland (Grønlands Geolo-

\section{Reference}

Escher, A. \& Watt, W. S. (edit.) 1976: Geology of Greenland, 603 pp. Copenhagen: Geol. Surv. Greenland.

M. G., Geological Survey of Greenland, Copenhagen.

\author{
Peter R. Dawes
}

giske Unders $ø$ gelse or GGU) was founded in 1946 with headquarters in Copenhagen. GGU's first expedition reached Greenland that summer.

The idea of regional map sheet coverage had emerged much earlier. It was initiated when exploration in northern Greenland between 1916 and 1923 aimed, somewhat ambitiously, at the production of a series of coloured map sheets at a common scale covering the vast region between Baffin Bay and the Greenland Sea. In fact the series came to be issued as five maps each on a different scale (Dawes \& Haller, 1979). The name of the Danish geologist/cartographer Lauge Koch is firmly associated with this phase of geological work in Greenland. It was also Koch who organised the first regional mapping expeditions (between 1926 and 1958) in East and North-East Greenland that resulted in map sheets on a common scale $(1: 250000)$ covering the region between $72^{\circ}$ and $76^{\circ} \mathrm{N}$ (fig. 1; Koch \& Haller, 1971).

Koch's expeditions operated in the remote and logistically difficult regions of Greenland, along the north and east coasts, characterised by major Palaeozoic fold belts. Thus, when GGU was founded to take care of the systematic geological investigation of Greenland, it naturally directed its initial activity to regions not being surveyed by the Koch expeditions. It concentrated its resources in what happened to be the geologically much less well-known, but inhabited regions of the west coast with the vast expanses of Precambrian crystalline rocks. Moreover topographical mapping of this coast was relatively well advanced and exploitation of mineral deposits that might arise from the systematic mapping would 


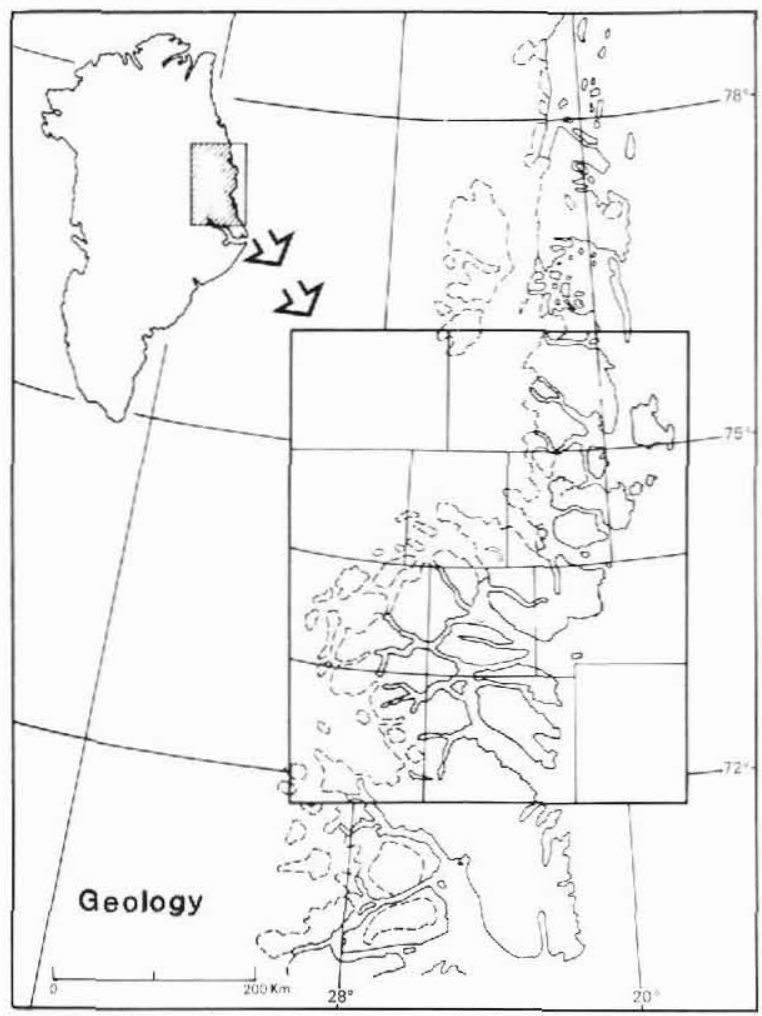

Fig. 1. Index map showing the individual map sheets making up the 'Geological Map of East Greenland' at scale 1:250 000 . The maps were printed in 1965. Reproduced from Koch \& Haller (1971) with slight modification.

be generally easier to develop on a more accessible coast. The national commitment for the publication of a systematic geological map series arose with the emergence of GGU as the state's sole scientific organisation responsible for geological affairs in Greenland. Government funding of 'Koch's East Greenland expeditions' ceased in 1958.

Early reconnaissance mapping by GGU was mainly restricted to coastal areas of West Greenland south of $71^{\circ} \mathrm{N}$. The results of the initial ten year period were published as a 1:500 000 map covering the region between $63^{\circ} 45^{\prime} \mathrm{N}$ and $69^{\circ} \mathrm{N}$ (Noe-Nygaard \& Ramberg, 1961). At the end of the 1950's the geological mapping gathered momentum, techniques changed and inland areas became accessible by helicopter. GGU entered a period of expansion and increased manpower could be engaged in the systematic mapping of south-western Greenland, most of which was undertaken at 1:20000 scale with a view to publication at 1:100 000 (Ellitsgaard-Rasmussen, 1961).

In the early 1960s mapping strategy was modified again and, in order to meet commercial business in- terests, more emphasis was placed on map production at a scale of 1:500 000. Thus a four-year programme was initiated in 1964 to produce a set of four regional maps covering the west coast at 1:500 000 . Concurrently with this the detailed 1:100 000 mapping continued in southwestern Greenland. The four-year project was followed by major field mapping programmes leading to both 1:500 000 and 1:100 000 maps in East Greenland $\left(69^{\circ}-\right.$ $72^{\circ} \mathrm{N}$ in 1968-72) and across North Greenland (1978-80, 1984-85). Present operations are centered in NorthEast Greenland $\left(75^{\circ}-78^{\circ} \mathrm{N}\right)$ and in central West Greenland (around $69^{\circ} \mathrm{N}$ ); these activities are reported on elsewhere in this volume (see Henriksen, 1990; Kalsbeek, 1990).

\section{National map sheet coverage}

The index and production status of standard map sheets at scales 1:500 000 and 1:100 000 (geology), and Quaternary geology at 1:500 000, are shown in figure 2 . These coloured maps are designed to be issued either singly or grouped, accompanied by map descriptions. However, many sheets have been issued separately to speed distribution. Extracts of maps of these two series, as well as other GGU maps, are illustrated in figure 3.

Both bedrock geology map series vary with respect to the detail and nature of geological information portrayed. This is naturally bound up with the historical development of geological research in Greenland. Thus the initial 1:100 000 map sheets from south-western Greenland, based on detailed mapping for the most part at 1:20000 scale, contrast with other sheets that are based on more reconnaissance-type investigations aided by appreciable aerial-photographic interpretation; for example, some of the sheets north of $71^{\circ} \mathrm{N}$ on the west coast. Likewise the 1:500 000 maps from south-western Greenland (nos 1 and 2), compiled directly from the 1:100 000 maps by simplification of detailed information, contrast with the map sheets from the south-eastern coast (nos 13 and 14) that are to a large extent based on reconnaissance observations from aircraft.

1:500 000 series. The first sheet in this series of 14 maps was published in 1971; by the end of 1989 eight map sheets had been published. Two more maps (nos 5 and 14) are in the compilation-draughting stage and should be published in 1990-91. Four sheets remain (nos 6, 9, 10 and 11). The southernmost one (sheet no. 11) between $72^{\circ}$ and $75^{\circ} \mathrm{N}$ in North-East Greenland is already covered by the 1:250 000 maps from the Koch expeditions described earlier (fig. 1) and as such is of low priority to be finished. Field work in the region between $75^{\circ}$ and $78^{\circ}$ in the area of map sheet no. 10 was begun in 1988 and will continue until 1990. Although 
some data for the remaining maps (nos 6 and 9) are in GGU files, the outstanding field work in these regions is not scheduled to take place until after 1993.

1:100 000 series. The first 1:100 000 map sheets of areas of south-western Greenland were printed in 1967 and 1968. From the early 1970's map sheets have been issued regularly and by the end of 1989 fifty sheets had been published. Several others are in the compilationdraughting stage. Present field work (1988-89) around $69^{\circ} \mathrm{N}$ in central West Greenland and its planned continuation in 1991-92 is scheduled to produce several 1:100 000 sheets. However, due to changing priorities GGU is currently concentrating its mapping resources into production of 1:500 000 maps, with a consequent decline in the production of 1:100 000 sheets.

Quaternary series. Standard maps showing the Quaternary geology of the ice-free areas are published at the scale of 1:500 000 (fig. 3F). The original intention was the production of a map series on the same index as the bedrock series (fig. 2). However, publication has been sporadic. The first map was released in 1974 and only four maps have been published by the end of 1989 (nos $1,2,3$ and 12). Due to general cuts in resources no other 1:500 000 map sheets are in the compilationdraughting stage. Moreover, Quaternary map sheet coverage of North Greenland, planned to be issued in the next few years, will be published at the reduced scale of 1:1000 000 .

\section{Other maps}

In addition to the systematic (standard) map sheet coverage described above, GGU also publishes a range of other maps - both single maps at various scales, as well as maps in series. Four such map types are discussed below. Of the single maps, many detailed geological (both bedrock and surficial geology) and structural maps have been issued to accompany reports, bulletins and other GGU publications (e.g. fig. 3D). In addition various special topic maps over specific areas have been occasionally released, for example, those featuring sea-floor geology, offshore seismo-stratigraphy and sediment isopachs, aeroradiometric anomalies, sub-glacial topography and hydrological aspects both over land and the Inland Ice margin.

General geological maps. Two general maps covering the whole of onshore Greenland have been published at a scale of 1:2500 000. A bedrock tectonic/geological map was published in 1970 (fig. 3A); a Quaternary geology map, also featuring surface and substratum contours of the Inland Ice, was issued the following year (fig. 3E). A new edition of the coloured bedrock map, including the geology of the continental margin, is planned. Over the years GGU has contributed general geological maps, including tectonic and metamorphic maps, at other scales (commonly between 1:1 000000 and 1:5000 000) to many international map programmes concerned with regional compilations of Europe, North America, the North Atlantic and the circumpolar arctic region.

Aeromagnetic maps. Coloured aeromagnetic anomaly maps over onshore and offshore areas based on data collected by GGU have been published at scales of 1:500 000 and 1:1000 000. The coverage of the five maps so far issued is given in figure 2 . The map covering part of the west coast was printed in 1984; the four sheets from the east coast were issued in 1988 (fig. 3G). As more data become available other sheets will be compiled, including maps at 1:1000 000 covering the Inland Ice.

Bathymetric maps. In 1974, GGU published a series of 86 bathymetric maps covering parts of offshore West and South-West Greenland between $59^{\circ}$ and $69^{\circ} 30^{\prime} \mathrm{N}$ (fig. 2). These maps, at a scale of 1:100 000 and showing a $10 \mathrm{~m}$ contour interval, show in great detail the sea floor topography of this segment of the continental margin. The maps were compiled from data obtained by the Royal Danish Hydrographic Office over a 20-year period from 1947. They were issued at the time of appreciable offshore exploration activity by commercial petroleum companies.

Geochemical maps. South-western Greenland, south of $61^{\circ} 30^{\prime} \mathrm{N}$, is covered by geochemical maps at the scale of 1:1 000000 . The publication is made up of 26 maps printed in 1982. The maps, designed as colour grid plots (fig. $3 \mathrm{H}$ ) showing the distribution and concentration of 19 elements, are the result of an uranium exploration project carried out in 1979-81 and based on field sampling and airborne gamma-spectrometry.

Fig. 2. Present status of four map series issued by the Geological Survey of Greenland. The bathymetric maps offshore West Greenland can be located with reference to the island of Disko named on map C. 


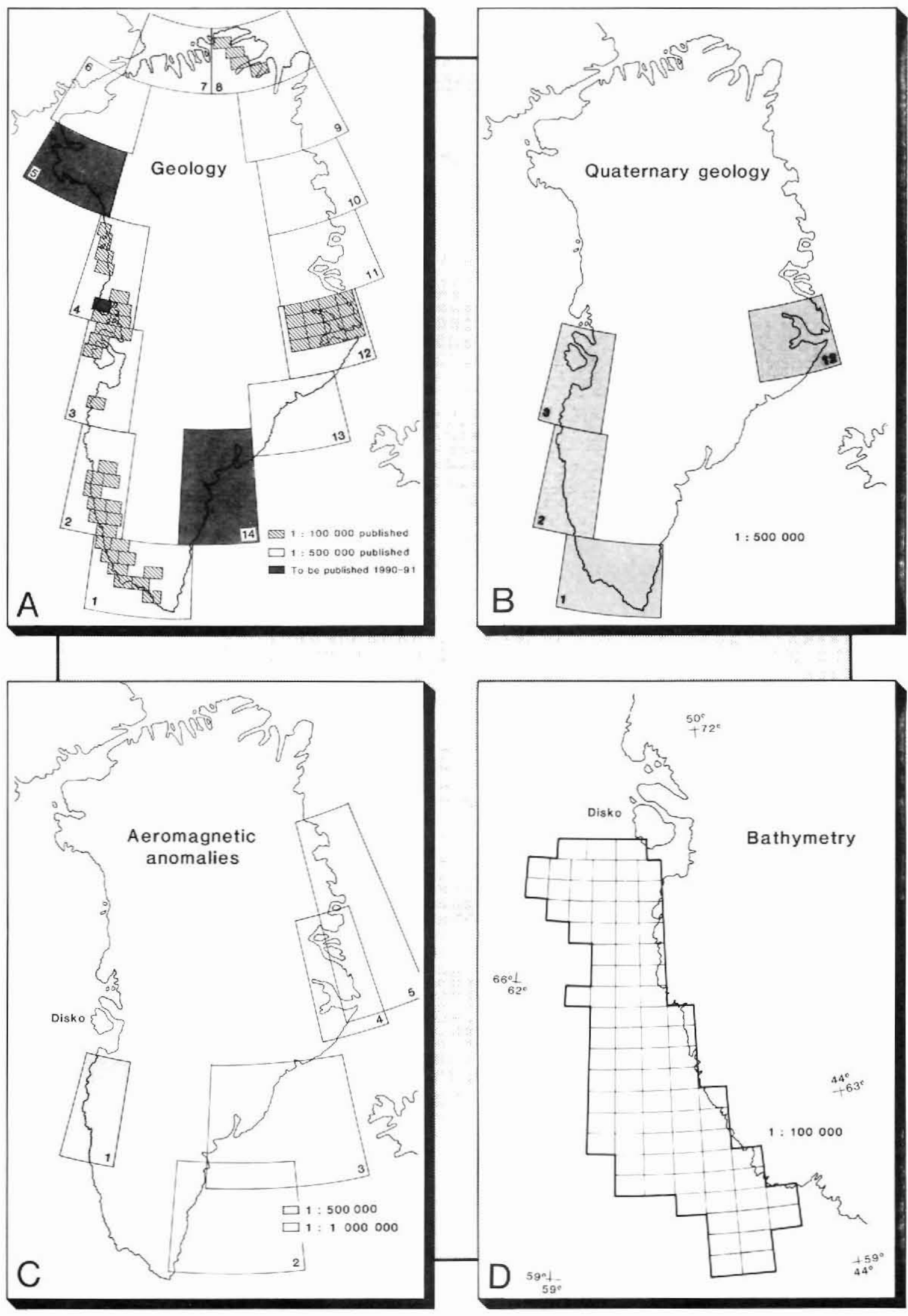




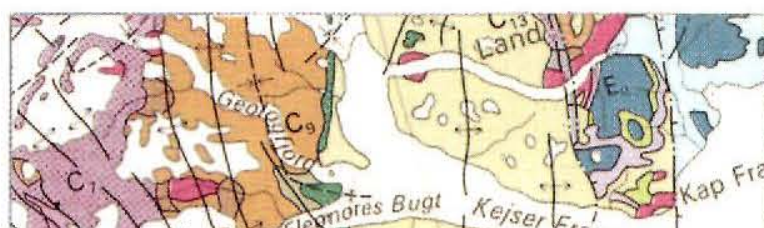

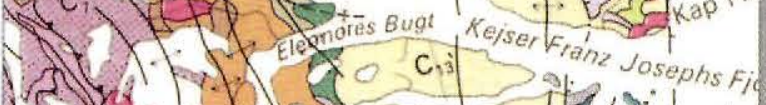
15 a

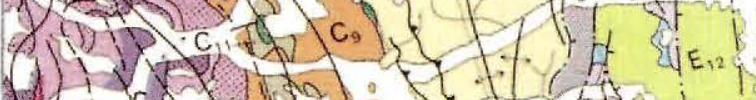

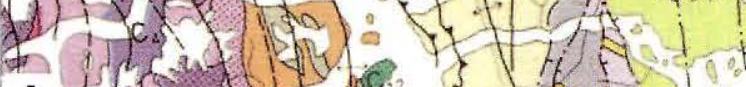

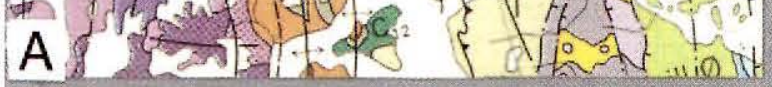
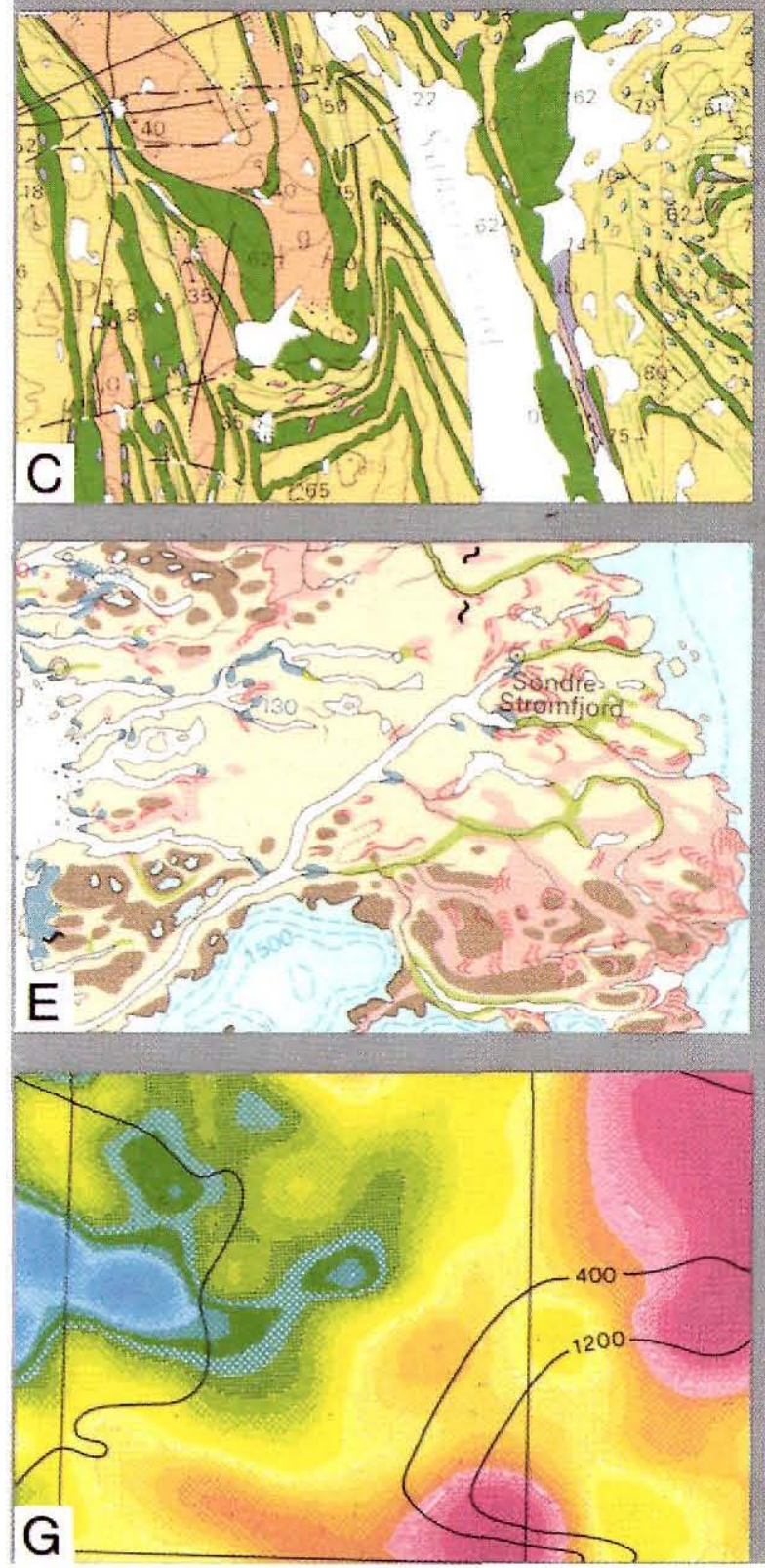
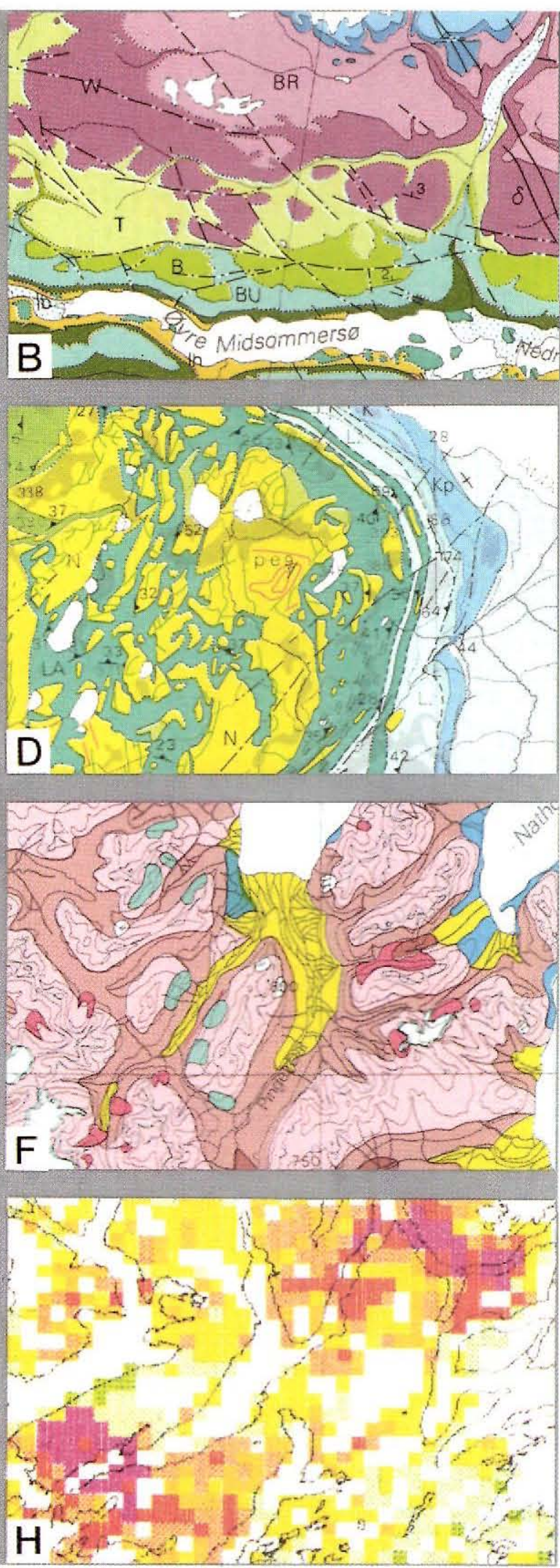


\section{Future developments}

Since the establishment of GGU and its development into a modern research organisation, classical onshore geological mapping has figured prominently in its activities. However, the resources available for such work are expected to decline in the next decade. A general cut in government funding, together with increasing commitment to applied geology and the direct assessment of economic potential, has led to a change of emphasis. This includes an awareness that the continental shelf is an integral part of Greenland and as such is a target for systematic investigation and mapping. Geological maps remain an essential source for an effective assessment and exploitation of energy and mineral resources, as well as for the development of geotechnical projects. Oil, gas, mineral and water energy, as well as metalliferous deposits are all prominent in Greenland's spectrum of natural resources. Detailed onshore geological mapping will be concentrated in those areas where economic potential is deemed to be the most promising. Geophysical mapping of the little-known offshore sedimentary basins will continue. Completion of the national map coverage at 1:500 000 occupies the highest priority as regards systematic map production.

Digitalisation of data and computer-supported graphic representation are now integral parts of GGU's map-making procedure and computerised photogram-

Fig. 3. Facsimile extracts of eight coloured map types issued by the Geological Survey of Greenland. All reproduced at the published scale.

A: 1:2 500000 Tectonic/geological map of Greenland, compiled by A. Escher, printed 1970. Extract is of North-East Greenland.

B: 1:500 000 standard map series, geology, Peary Land, North Greenland, sheet 8, compiled by H.-J. Bengaard \& N. Henriksen, printed 1984.

C: 1:100 000 standard map series, geology, Fiskefjord 64 V.1 Nord, West Greenland, compiled by A. A. Garde, printed 1989.

D: 1:20 000 special project map, geology, Ilímaussaq igneous complex, South Greenland, compiled by S. Andersen, $\mathrm{H}$. Bohse \& A. Steenfelt, printed 1988.

E: 1:2 500000 Quaternary map of Greenland, compiled by A. Weidick, printed 1971. Extract is of West Greenland.

F: 1:500 000 standard map series, Quaternary geology, Scoresby Sund, East Greenland, sheet 12, compiled by S. Funder, printed 1988.

G: 1:1000000 Aeromagnetic anomaly map of Greenland, sheet 3, compiled by L. Thorning, printed 1988.

H: 1:1 000000 Geochemical map of South Greenland, map 3, Maximum uranium airborne radiometric map, printed 1982. metrical techniques were introduced over a decade ago. The first special maps based on digitilisation of both geology and topography with automatic computer-controlled plotting have already been produced. Although these techniques are likely to be utilised on an increasing scale for special topic maps, the production of the 1:500 000 national map series is likely to be completed by conventional compilation and draughting.

The next decade will see an increase in geophysical and geochemical mapping exploiting the possibilities of computerised mapping techniques, with the publication of computer-produced thematic maps, for example, magnetic, electro-magnetic, gravimetric and radiometric maps, as well as plots of various elements and mineral occurrences.

Acknowledgement. This paper is a modified version of an invited article written for a special issue of Géochronique, Paris, on 'Development of geological mapping in Western Europe'. The original article was published in French: Géochronique, no. 92, p. 19-21, 1989.

\section{References}

Dawes, P. R. \& Haller, J. 1979: Historical aspects in the geological investigation of northern Greenland. Part 1: New maps and photographs from the 2nd Thule Expedition 19161918 and the Bicentenary Jubilee Expedition 1920-1923. Meddr Grønland 200(4), 3 maps, 38 pp.

Ellitsgaard-Rasmussen, K. 1961: Geological investigation of Greenland: past and present. In Raasch, G. O. (edit.) Geology of the Arctic 2, 1185-1187. Toronto: University of Toronto Press.

Henriksen, N. 1990: Regional geology and 1:500 000 mapping in North-East Greenland. Rapp. Gronlands geol. Unders. 148 (this volume).

Kalsbeek, F. 1990: Disko Bugt Project, central West Greenland. Rapp. Grønlands geol. Unders. 148 (this volume).

Koch, L. \& Haller, J. 1971: Geological map of East Greenland $72^{\circ}-76^{\circ} \mathrm{N}$. lat. $(1: 250,000)$. Meddr Grønland 183, 13 sheets, $26 \mathrm{pp}$.

Noe-Nygaard, A. \& Ramberg, H. 1961: Geological reconnaissance map of the country between latitudes $69^{\circ} \mathrm{N}$ and $63^{\circ} 45 \mathrm{~N}$, West Greenland. Grønlands geol. Unders. Geological Map 1, 2 sheets, 9 pp. (also Meddr Grønland 123(5)).

P. R. D., Geological Survey of Greenland, Copenhagen. 